\title{
The Mycococcus Form of Mycobacteria
}

\author{
By ANNA CSILLAG \\ The Medical Research Council's Unit for Research on Drug Sensitivity in \\ Tuberculosis, Postgraduate Medical School of London, Ducane Road, London, W. 12
}

(Received 28 October 1963)

\begin{abstract}
SUMMARY
Cultures of form 2 mycobacteria, which had been recently isolated from form 1 of strains of Mycobacterium tuberculosis and atypical mycobacteria, were cultivated on nutrient agar in screw-capped bottles and kept unopened for 6 weeks at room temperature. Gram-positive granules developed in organisms which had penetrated into the medium. When these organisms were incubated in digest broth at $37^{\circ}$ with intermittent aeration, the granules were liberated into the medium and gradually increased in size to that of a small coccus. After a resting period of about 2 weeks, the 'cocci' started to multiply independently, forming diplococci and tetrads. At this stage the cocci yielded colonies on subculture on nutrient agar. The cocci were identified as members of the genus Mycococcus, family Mycobacteriaceae, order Mycobacteriales (Krassilnikov, 1959). Mycococci were not obtained in broth cultures which were either not aerated or were aerated frequently or continuously. Prolonged subcultivation of the parent form 2 strains on nutrient agar prevented the development of mycococci in broth. Evidence, such as the failure to isolate mycococci from uninoculated but aerated media, is submitted that the mycococci were not contaminants. Previous work on isolation of similar cocci from different members of the order Actinomycetales, including human and bovine strains of $M$. tuberculosis is reviewed.
\end{abstract}

\section{INTRODUCTION}

It has been previously reported (Csillag, 1961, 1962) that strains of Mycobacterium tuberculosis grown for 14-27 weeks on inspissated or autoclaved LöwensteinJensen medium with intermittent aeration yielded, on subculture onto nutrient agar, rapidly growing not acid-fast, endospore-forming organisms (form 2 mycobacteria). In primary isolation the majority of the form 2 mycobacteria were bacilli, but some were cocci (Csillag, 1961). When grown for a short period on nutrient agar, the morphology of the form 2 mycobacteria resembled that of certain Bacillus species (Csillag, 1961), but when cultivated for sufficiently long in slideculture, so that the bacillary morphology could be examined undisturbed, the lifecycle of these organisms was found to be complex, and resembled that of certain species of the Actinomycetaceae (Csillag, 1963a). In slide-culture, septate pseudobranching filaments were first formed; these fragmented first into bacillary elements and later a few of the bacilli fragmented into coccoid elements. In anaerobic culture, the coccoid elements continued to multiply by binary fission, which occurred in any plane, to form diplococci, tetrads and sarcina-like configurations, in which the individual cocci varied considerably in size. The formation of coccoid elements could 
not easily be studied in the slide cultures, since it occurred rather infrequently. A further method for producing cocci regularly and in large numbers was therefore elaborated. This method, described here, and referred to elsewhere (Csillag, 1962, $1963 b, c)$, has been used for the identification of 131 strains of form 2 mycobacteria during the past 2 years.

\section{METHODS \\ Organisms}

Mycobacterium tuberculosis. Most of the work was done with a form 2 strain isolated (Csillag, 1962, method no. 2) from a drug-sensitive nicotinamide-positive form 1 strain (I 1413) obtained from the sputum of a British patient with pulmonary tuberculosis. The morphology in slide culture and certain other characteristics of this form 2 strain have been described (Csillag, 1963a, $b$ ). A further 23 strains were obtained from newly diagnosed untreated British patients with pulmonary tuberculosis, and 18 strains from corresponding South Indian patients participating in chemotherapy studies at the Tuberculosis Chemotherapy Centre, Madras. A BCG strain (Statens Seruminstitut, Copenhagen) and strain H $\mathbf{3 7}$ RV were included.

Other mycobacteria. Group I (Runyon, 1959) anonymous mycobacteria, 3 strains; group II, 2 strains; group III, 3 strains; group IV, 5 strains, obtained from Dr E. H. Runyon, Salt Lake City, Utah, or described by Selkon \& Mitchison (1959).

Bacillus licheniformis (NCTO 1158) and Bacillus subtilis (NCTC 2591)

Media. (1) Hartley's digest broth (Mackie \& McCartney's Handbook, 1960) was prepared with the following modifications: $(a)$ distilled water was used instead of tap water; $(b)$ a double amount of pancreatic extract was used. The medium was dispensed in $8 \mathrm{ml}$. amounts in $\frac{1}{2}$-oz. bottles with screw-caps, which were checked for tight fitting. (2) Nutrient agar was prepared by addition of $1 \cdot 4 \%(w / v)$ agar to meat extract + peptone-broth (Oxoid No. 2, Oxo Ltd., London), was dispensed in $4 \mathrm{ml}$. amounts in $\frac{1}{2}$-oz. screw-capped bottles. (3) Peptone broth was prepared by adding $1 \%$ peptone (Evans Medical Ltd., Liverpool) to the digest broth and was dispensed in $10 \mathrm{ml}$. amounts in $6 \times \frac{5}{8}$ in. test tubes plugged with cottonwool. (4) Peptone agar plates were made with nutrient agar containing an additional $1 \%$ peptone. All media were autoclaved at $120^{\circ}$ for $15 \mathrm{~min}$. (5) Human blood medium as described by Tarshis et al. (1955), but without penicillin or agar, was dispensed in $8 \mathrm{ml}$. amounts in $\frac{1}{2}$-oz. screw-capped bottles. (6) Undiluted horse serum, sterilized by filtration, was dispensed in $8 \mathrm{ml}$. amounts in $\frac{1}{2}$-oz. screw-capped bottles. All media were incubated before use at $37^{\circ}$ for 4 days and at room temperature for another 3 days, as a test of sterility.

Manipulation and cultivation. Inoculation and aeration of the cultures was done in an arm-hole cabinet, previously irradiated with ultraviolet (u.v.) radiation. Plates were sealed in polythene bags during incubation. All cultures were incubated at $37^{\circ}$ unless otherwise stated.

Staining methods. Smears were allowed to dry under u.v. lamp and were fixed in methanol. Jensen's method for Gram staining (Mackie \& McCartney's Handbook, 1960) was modified by decolorizing rapidly with acetone and counterstaining with 
dilute (1/15) carbol fuchsin. All dye solutions were filtered through filter paper (Whatman, No. 2) immediately before use.

Isolation of cocci from form 2 mycobacteria. Cocci were obtained from form 2 mycobacteria as follows. Soon after its isolation from the form 1 strain, the form 2 culture was purified twice by single colony selection on nutrient agar. After incubation for 2 days, a colony from the second plate ('initial culture') was inoculated on to a nutrient agar slope, which was incubated for 3 days with the cap loose until sporulation had occurred. The cap was tightened and the slope left unopened at room temperature for 6 weeks ('old culture'). About $2 \mathrm{mg}$. (moist weight) of the growth, including portions of the colonies that ramified below the surface of the medium, was added to bottles containing $0.4 \mathrm{ml}$. sterile distilled water and glass beads. After the bottles had been shaken mechanically for $1 \mathrm{~min}$., about $0.1 \mathrm{ml}$. of the suspension was inoculated into several screw-capped bottles of digest broth ('test cultures'). The test cultures were then incubated, and were aerated, first at the 7th day after inoculation and therafter once a week. Aeration was performed by flaming the cap, removing the cap for about 20 sec. while holding the opening of the bottle over the flame, and then replacing the cap firmly. The bottles were then swung gently by hand to settle the pellicle of growth while leaving the sediment undisturbed and were incubated, with particular care to avoid accidental shaking. At each aeration, one of the test cultures was investigated by removing, with a Pasteur pipette, macroscopically visible floccules of the undisturbed sediment, some of which were stained, and the remainder inoculated on two nutrient agar plates. These plates were incubated for 1 day. Each test culture was discarded after sampling.

The following controls were always included. (1) Inoculum controls: all cultures used for inoculating other media (initial culture, shaken suspension) were each spread on 8-10 nutrient agar plates, which were incubated for 2 days. Colonies were examined and smears made from 5-6 isolated colonies and from the pool of each plate to exclude the presence of cocci. (2) Contamination controls: the same number of bottles of digest broth as were used for the test cultures were 'inoculated' with a sterile loop and were subjected to all subsequent procedures (including aeration) in the same manner.

\section{RESULTS}

\section{Origin of cocci from form 2 mycobacteria}

The colonial and bacillary morphology of the cultures of form 2 (strain I 1413) which preceded the test cultures were as follows:

(1) Initial culture. The colonies were 3-6 mm. diam. at $48 \mathrm{hr}$ with a finely granular, 'beaten-copper' surface (Pl. 1, fig. 1). The growth was easily emulsified, but the colonies ramified under the surface of the medium and could not be removed without disrupting it. The colonies were composed of Gram-negative rods which sometimes contained endospores, but never contained granules (Pl. 1, fig. 2).

(2) Old cultures. After incubation at room temperature for 6 weeks, the old culture consisted of free endospores and a few Gram-variable vegetative organisms, some of which contained Gram-positive granules (0.1-0.3 $\mu$ diam.).

(3) Shaken suspension. After shaking, the suspension of the old culture contained extra-cellular Gram-positive granules (0.1-0.3 $\mu$ diam.). Cocci were never obtained from cultures in which liberated granules were not present. Deviation from the 
procedure described above often resulted in a failure to yield granules or in their disappearance from the culture.

(4) Test cultures. After incubation for $24 \mathrm{hr}$, the medium of the test cultures was unchanged except for a slight flocculent deposit. At 7 days, and after each subsequent aeration, a thin surface pellicle was formed, which submerged during the shaking. After 4 weeks, no new pellicle was formed and the medium became turbid.

In the serial smears from the test cultures, particles of the sedimented pellicle stained slightly pink. The pink patches from the 7-day test cultures contained uniformly stained Gram-variable rods, often long (Pl. 1, fig. 3), and occasional endospores. At 14 days, the filamentous rods had fragmented into short rods, some of which contained Gram-positive granules, most often in the poles (Pl. 1, fig. 4). Free endospores were still present. At 21 days, more granules were present in the rods and some were extracellular ( $\mathrm{Pl}$. 1, fig. 5). At about 28 days, a greater proportion of the granules had been liberated and these varied in size from just visible to small circular cocci $(0 \cdot 7 \mu$ diam.; Pl. 1, fig. 6). At about 35 days, many of the rods began to disintegrate, leaving chains of distinctly stained granules surrounded by an indistinct pink cell wall ( $\mathrm{Pl}$. 1, fig. 7). At the same time, some of the free cocci elongated (Pl. 1, fig. 8). At 42 days, some of the cocci divided to form diplococci (Pl. 1, fig. 9), tetrads or irregular clumps. Gram-variable rods, which stained weakly, were also present, but no endospores. At 60 days, when the experiment was terminated, most of the cultures consisted entirely of cocci; a few still contained rods undergoing lysis.

Subculture of the test cultures on to nutrient agar plates yielded the following results. When the test cultures had been incubated for less than 42 days and contained intracellular or extracellular granules which had not started independent division, the colonies on nutrient agar were similar to those described for the initial culture (PI. 1, fig. 1). However, when the large free-lying coccal elements had begun to multiply to form diplococci or tetrads (42 days), subculture yielded an additional type of colony. These colonies were variable in size $(0 \cdot 3-1 \cdot 0 \mathrm{~mm}$. diam.), circular with an entire edge, raised, white and smooth (Pl. 1, fig. 10). Smears from the colonies showed Gram-positive cocci of uneven shape (circular, ovoid, irregular) and size $(0.3-0.7 \mu$ diam.), lying singly, in pairs or in irregular clusters (Pl. 1, fig. 11). No cocci were seen on the inoculum-control plates or in the smears made from them. The contamination-control plates remained sterile.

\section{Description of the coccal strain}

Soon after its isolation the coccal strain was purified three times by single colony selection on nutrient agar. After incubation for 2 days, a colony was inoculated on to 10 peptone agar plates and into 10 peptone broth tubes. The plates were incubated at $37^{\circ}$ for 1 day and then kept at room temperature for a further 13 days; the tubes were incubated at $37^{\circ}$ for 14 days. Half of the tubes and plates were examined at 1 day and the other half at 14 days.

The colonies on the plates at 1 day were similar to those obtained in the first isolate, but they were more irregular in size $(0.3-1.3 \mathrm{~mm}$. diam.; Pl. 2, fig. 1). At 14 days, the colonies had increased in size $(1 \cdot 0-5 \cdot 0 \mathrm{~mm}$. diam.), their edges were slightly irregular and the surface was differentiated into a central dense area, an intermediate, less opaque zone and a translucent periphery (Pl. 2, fig. 2); daughter 
colonies were often present on the surface. Smears from the 1-day colonies showed circular or slightly elongated Gram-positive cocci, arranged singly, in pairs or in clusters; their size was variable $(0 \cdot 4-1 \cdot 0 \mu$ diam.; Pl. 2, fig. 3). The cocci on the 14-day plates were still Gram-positive; their shape was more irregular than before, with thick (Pl. 2, fig. 4) or thin (Pl. 2, fig. 5) elongated forms present. Some of the cocci appeared to be dividing by binary fission in successive planes at right angles to each other (Pl. 2, fig. 6).

The peptone broth cultures were, at 1 day, slightly turbid with a powdery sediment; at 14 days, the turbidity had increased and the sediment was very mucoid. The morphology of the cocci at 1 day was similar to that on the solid medium, but at 14 days the shape of the organisms was more variable. Crescentshaped (Pl. 2, figs. 7 and 8), triangular (Pl. 2, fig. 9), pinched or nearly rectangular organisms were observed. Small numbers of Gram-variable fine short rods were also present ( $\mathrm{Pl}$. 2, fig. 10). Some of the cocci appeared ring-shaped, being unstained at the centre; some cocci were more deeply stained than the rest and a few of these produced short germination tubes (Pl. 2, fig. 7). In a few organisms, multiplication by lateral budding was observed (Pl. 2, fig. 10). A broth culture was sterilized by autoclaving for $5 \mathrm{~min}$. at $15 \mathrm{lb}$./sq.in. After incubation for 14 days the peptone broth cultures and 4 colonies from each plate were plated out on nutrient agar. Only colonies of cocci, similar to those described above, were obtained. On the basis of the above description the coccal strain was identified as belonging to the genus Mycococcus, family Mycobacteriaceae, order Mycobacteriales (Krassilnikov, 1959).

\section{Influence of aeration on the isolation of mycococci}

The influence of aeration on the isolation of mycococci from the form 2 of strain I 1413 was studied in three experiments. (1) Cottonwool plugs were inserted in the neck of 12 test cultures, below the screw caps. These cultures were aerated intermittently (in the rhythm previously described) by loosening the caps and leaving them loose for $3 \mathrm{hr}$. Mycococci were isolated on nutrient agar from 9 of the 12 test cultures within 28 days. The cottonwool plugs in the necks of the remaining 3 cultures became soaked with broth and mycococci were not isolated from these within 40 days. (2) A further group of 12 test cultures was divided into 6 cultures which were aerated intermittently, but without cottonwool plugs, and 6 which were not aerated. The cultures that were aerated intermittently all yielded mycococci within 41 days, while the cultures that were not aerated did not develop pellicles and did not yield mycococci within 90 days. (3) A further group of 18 test cultures was divided into three groups of 6 each, which were either (i) aerated intermittently (as described above) without plugs, (ii) were aerated three times a day without plugs, or (iii) were exposed in a moist chamber to continuous aeration through plugs (the bottles not being capped). Mycococci were isolated from all of the first group of cultures (aerated intermittently) within 32 days, but were not isolated from any of the remaining cultures within 50 days.

\section{Multiplication of mycococci in digest broth in the absence of form 2 mycobacteria}

A 5-hr shaken, digest broth culture of the mycococcus of strain I 1413 was serially diluted in tenfold steps. From each dilution, $0.2 \mathrm{ml}$. was added to each of two bottles of digest broth, which were incubated for 1 day or 4 days, with their 
caps closed. After incubation, $\mathbf{0} \cdot \mathbf{2} \mathbf{~ m l}$. from each bottle was plated on nutrient agar. The bottles seeded from the $10^{-6}$ and the $10^{-7}$ dilutions yielded innumerable colonies on nutrient agar when incubated for 1 day. Of the bottles seeded with the $10^{-8}$ dilution, the one incubated for 1 day yielded 5 colonies, and the one incubated for 4 days yielded 142 colonies. The bottles seeded with the $10^{-9}$ and $10^{-10}$ dilutions remained sterile. Mycococci in pure culture were also shown to grow freely in plugged test tubes in an aerobic and in an anaerobic atmosphere.

\section{Stabilization of form 2 mycobacteria by frequent subcultivation}

In all experiments described so far, mycococci were obtained from the form 2 strains at 6 months or less after their isolation from the form 1 cultures of strain I 1413. However, in further experiments, the form 2 strain was maintained, as described previously (Csillag, 1963a) for longer periods, by successive subcultivation on nutrient agar at intervals of 2 months. The mean period of incubation of the test cultures until mycococci were first isolated was 42 days for form 2 strain which had been maintained for 6 months, 51 days for a strain maintained for 11 months, 63 days for a strain maintained for 20 months, and mycococci were not isolated within 85 days when the form 2 strain had been maintained for 28 months.

\section{Isolation of mycococci from further form 2 strains}

Mycococci were isolated from the form 2 of 10 strains of mycobacteria (3 British and 3 Indian strains of Mycobacterium tuberculosis, strain BCG, 2 strains of group I and 1 strain of group III anonymous mycobacteria), first at 2 months after their isolation from the form 1 cultures and again after the form 2 strains had been maintained for 12 months and for 19 months. Strains of Bacillus subtilis and B. licheniformis were included in the first two experiments. In the first experiment, mycococci were isolated from the BCG strain after incubating the test cultures for 7 days, from the Indian and the anonymous strain, at between 13 and 24 days, and from the British strains after 33 days. In the second experiment, mycococci emerged more slowly, but were obtained first from strain BCG and last from the British strains. In the third experiment, only strain BCG yielded mycococci within 42 days. The Bacillus species did not yield mycococci.

Further experiments with the form 2 of 131 different strains of mycobacteria showed that most British strains of Mycobacterium tuberculosis yielded mycococci for the first time at 6 to 8 weeks, but a few yielded mycococci within 4 weeks or after 12 weeks. Mycococci were obtained for the first time at 2-4 weeks with Indian strains. The speed of emergence of mycococci was different in different test cultures of the same strain in the same experiment. It seemed probable that mycococci were obtained more rapidly when the 'old culture' had been left for long periods at room temperature.

Production of mycococci in blood and serum media. In further experiments similar to those described above, mycococci were obtained from test cultures of 57 form 2 strains in which human blood medium or undiluted horse serum was used in place of digest broth. 


\section{DISCUSSION}

The evidence that the mycococci were derived from the form 2 mycobacteria and did not arise from contaminants present in the inoculum, the culture medium or gaining access during aeration, is as follows. Mycococci were obtained only from test cultures which were aerated once a week and not from those aerated more frequently; contaminants would be expected to grow at least as frequently in the latter cultures as in the former. Further, the development of the cocci was followed in smears; free cocci were visible in the cultures at about the 28th day of incubation but were not viable on subculture until after another fortnight; contaminating organisms would be unlikely to show this 'resting period'. Finally, the procedure described has resulted in the isolation of mycococci from all of the numerous form 2 cultures studied. No other organisms have been isolated from these cultures and it would be remarkable if mycococci were the only type of contaminants to be found.

There are certain other reasons for the specific exclusion of the inoculum used for the test cultures as being contaminated with cocci. The cultures used for preparation of the suspension had been purified by single colony selection. The suspension itself was plated out on nutrient agar for the presence of cocci and these were never found. If contaminants had been present, growth of cocci would have been expected in the first few days of incubation of the test cultures, but they were isolated only at about 42 days. Finally, cocci were never obtained from cultures which had not been aerated, even though a small inoculum of a pure culture of mycococci grew freely under these conditions.

Contamination of the medium at the start of the experiments or during aeration is also unlikely since about 800 control cultures (in 20 separate experiments) which were 'inoculated' with a sterile loop and were aerated in the same manner as the test cultures failed to yield cocci. Furthermore, if the cocci were contaminants of this type, they would have been obtained from the form 2 cultures that had become stabilized. Finally, it might be argued that the cocci gained access to the cultures as contaminants, but were only able to grow in association with the form 2 organisms. However, the cocci grew freely from small inocula in the absence of the form 2 bacilli.

The serial examination of smears indicates that mycococci might have developed from form 2 mycobacteria by the following process. In the 'old cultures' some of the vegetative cells, mainly those which penetrated into the medium, developed intracellular granules, which were liberated during the shaking with glass beads. In the test cultures these granules, together with those which developed later in the sedimented pellicle, were incubated under microaerophilic conditions at the bottom of the tubes, where they gradually increased in size. After a long resting period, the cocci started to multiply independently and at this stage were capable of forming colonies on subculture to nutrient agar. Microaerophilic conditions appeared necessary, since mycococci were not isolated when the test cultures were aerated either continuously or three times daily, nor were they isolated when the test cultures were incubated with their caps closed throughout.

Frequent subcultivation of the parent form 2 strains resulted in the loss of the ability to produce mycococci, that is, in stabilization of the strain in the form of a spore-bearing rod. The same phenomenon was reported earlier (Csillag, 1963b), 
when it was also observed that stabilized cultures failed to yield pseudobranching filaments in slide culture. It is not yet known whether stabilization is a reversible process. If it were irreversible, some form 2 mycobacteria might be misclassified as bacillaceae. On the other hand, if it were reversible, organisms classified as bacillaceae might occasionally be found to produce mycococci. This could be the explanation of the findings of Appleby (1939) who isolated cocci which were morphologically similar to those described in the present paper, from aerated broth cultures of a Bacillus species. Moustardier, Dulong de Rosnay, Pasquier \& Latrille (1962) also observed cocci in cultures of Bacillus mesentericus, but these cocci did not multiply independently.

The cocci isolated from the form 2 mycobacteria were identified as mycococci on the basis of the description of Krassilnikov (1959) who regards mycococci as 'degraded' mycobacteria. In this description mycococci are defined as Grampositive cocci, whose most characteristic feature is the great variability in the shape and size of the cells within the same culture. They multiply by fission, lateral budding and by germination tubes which are produced by the resting cells in old cultures. Some species produce saltants which are indistinguishable from mycobacteria. On ordinary media mycococci are so closely similar to micrococci that it is easily possible that a number of the so-called micrococci belong in fact to the mycococci'. Krassilnikov (1934) found that only prolonged cultivation can reveal the true nature of mycococci and enable them to be distinguished from micrococci. According to Demikhovskii (1961) bacilliform cells can be found in all cultures of mycococci and these remain present even after serial purification. According to Nellis (1955) the germination of the resting cells of mycococci should be considered as analogous to the germination of the conidiospores of the Actinomycetes. Waksman (1961) also included the genus Mycococcus within the Actinomycetales, but did not regard them as 'true' Actinomycetes. In a tentative phylogeny of Actinomycetales, Jensen (1953) suggested that the starting point might be a coccoid organism leading via mycococci and coryneform bacteria to the acid-fast mycobacteria and to the potentially acid-fast nocardia.

Similar observations to those described in the present paper have been reported earlier with different members of the families Actinomycetaceae and Mycobacteriaceae. In cultures of some Actinomycetaceae cocci appear regularly as a result of fragmentation of the vegetative mycelium (Henrici, 1947; Waksman, 1961). With some strains, cocci are produced in such a large number that, after prolonged incubation, nothing but cocci are seen in smears (Topping, 1937). The cocci are similar in shape and size to the spherical bacteria (Waksman, 1959) and, after being produced, continue to divide by binary fission (Henrici, 1947). When subcultivated into suitable medium the cocci usually develop into fresh mycelium either by forming germination tubes or by lateral budding (Waksman, 1961), but under exceptional circumstances they can be maintained in subcultures for several generations as cocci and even 'stabilization in this form is not improbable' (Lieske, 1921). Coccal strains were isolated from 16 strains by Koelz (1933) and from further strains by Luksch (1930) and Novak \& Henrici (1933). Colien (1935) obtained a coccus from a human throat. This coccus then yielded a filamentous organism which reverted later to the original coccal form. The coccus was reinvestigated by Gillespie \& Bowen (1936) and was identified as the final form of an Actinomyces-like organism. Some 
authors (for instance, Waksman, 1959) considered that cocci, which had been isolated from Actinomycetaceae, were mutants or variants, but others (Krassilnikov, cit. Waksman, 1959) regarded these cocci as a stage in the normal development of nocardia, rather than as mutants.

The appearance of cocci in cultures of mycobacteria had also been reported by several authors (Sweany, 1928; Kahn, 1929; Karwacki, 1929; Fontes, 1931; Pla Y Armengol, 1931; Vaudremer, 1931; Lindegren \& Mellon, 1933; Mellon, Richardson \& Fisher, 1933; Weissfeiler \& Dwolaitskaja-Berischew, 1935; Kölbel, 1951; Xalabarder, 1954, 1958; Juhasz, 1962; Mazet, 1962). In most instances these cocci were described as being uneven in size and appearing in pairs or in tetrads. Since tetrads were observed, the organisms must have been capable of dividing in different planes, a characteristic regarded as essential in the identification of a coccus (Bisset, 1962) and differentiating the organism from short rods, which divide only in a single plane. Most authors regarded the appearance of cocci either as a part of the life-cycle of mycobacteria or as mutants. Some authors suggested that the cocci originate from the liberation of the Gram-positive granules which were first described in cells of mycobacteria by Much $(1907,1931)$. Sweany $(1926,1928)$ isolated granules with a micromanipulator and followed their development into cocci in hanging drop cultures. Vaudremer (1931) confirmed the results of Sweany. On the basis of investigations with the electron microscope, Xalabarder $(1954,1958)$ regarded the cocci as disjoint conidia, liberated from the micromycelium of mycobacteria. There are some reports on the isolation of cocci from cultures of mycobacteria and their subsequent maintenance in coccal form (Pla Y Armengol, 1931; Vaudremer, 1923; Krassilnikov, 1934; Kirchner, 1928; Møllgaard, 1931). Møllgaard isolated cocci from mycobacteria in two steps, closely similar to those described by the present author. He cultured mycobacteria (human and bovine strains) in yeast extract and obtained rapidly growing, not acid-fast, Gram-negative rods which later developed Gram-positive granules. The granular rods were later subcultivated in broth, where the granules developed into diplococci. The cocci which were isolated by these authors were not, however, described in sufficient detail to identify them with certainty as mycococci.

Further experiments to be described in due course have shown that the mycococci can be reverted to form 1 (acid-fast) and form 2 (spore-bearing) mycobacteria.

I am much indebted to Dr D. A. Mitchison, without whose help this work could not have been completed. I am grateful to $\mathrm{Mr}$ M. Clarke for his skilled and conscientious technical assistance.

\section{REFERENCES}

Appleby, J. C. (1939). Cytology and methods of reproduction of two cocci and the possible relation of these organisms to a spore-forming rod. J. Bact. 38, 641.

Bisset, K. A. (1962). Bacteria, 2nd edn., pp. 53, 80. Edinburgh and London: Livingstone.

Colien, F. E. (1935). A study of microbic variation in a yellow pigment producing coccus. J. Bact. 30, 301.

Csillak, A. (1961). Spore formation and 'dimorphism' in the mycobacteria. J. gen. Microbiol. 26, 97.

Csillag, A. (1962). Development of Form 2 mycobacteria on autoclaved LöwensteinJensen medium. Tubercle, Lond. 43, 439. 
Csillag, A. (1963a). Cellular morphology of Form 2 mycobacteria in slide cultures. J.gen. Microbiol. 30, 21.

Csillag, A. (1963b). Stabilization of various forms of Mycobacterium tuberculosis. Tubercle, Lond. 44, 368.

Csillat, A. $(1963 c)$. Growth of Form 2 mycobacterium and Bacillaceae on LöwensteinJensen medium. J. gen. Microbiol. (in the Press).

Demiknovskir, I. E. (1961). The species composition of the bacterial antagonists of the oral cavity. J. Microbiol., Moscorw, 32, 1529.

Fontes, A. (1931). Über die Filtrierbarkeit des Tuberkulosevirus vom Standpunkte des Polymorphismus. Beitr. Klin. Tuberk. 77, 2.

Girlespie, H. B. \& Bowen, M. (1936). The Actinomyces-like nature of a recently described 'unidentified' yellow pigment-producing coccus. J. Bact. 32, 127.

Henrici's Molds, Yeasts and Actinomycetes (1947), 2nd edn., pp. 350, 354. Ed. by C. E. Skinner, C. W. Emmons and H. M. Tsuchiya. London: Chapman and Hall.

Jensen, H. L. (1953). The genus Nocardia (or Proactinomyces) and its separation from other Actinomycetales, with some reflections on the phylogeny of the Actinomycetes, p. 69. Symposium, Actinomycetales. VIth Int. Congr. Microbiol. Roma: Fondazione Emanuele Paterno.

JuHasz, S. E. (1962). Aberrant forms of Mycobacterium phlei produced by Streptomycin and their multiplication on Streptomycin-free media. J. gen. Microbiol. 28, 9.

KAHN, M. C. (1929). A developmental cycle of the tubercle bacillus as revealed by single cell studies. Am. Rev. Tuberc. 20, 150.

KARWACKI, L. (1929). Morphologie des Strepthotrix obtenue par la transformation des bacilles tuberculeux. C.r. Séanc. Soc. Biol. 100, I, 214.

Kirchner, O. (1928). Studien zur Morphologie und Biologie des Tuberkulose-Erregers. III. Nichtsäurefeste Formen in Saponin-Glycerin-Bouillon Kulturen. Beitr. Klin. Tuberk. 70, 385.

KoElz, L. (1933). Ungewöhnliche Kokkenformen bei Actinomyces. Zbl. Bakt. (2), 88, 373.

KoLBEx, H. (1951). Untersuchungen am Mycobacterium tuberculosis. Z. Hyg. Infekt. $133,45$.

Krassilnikov, N. A. (1934). Die Entwicklungsgeschichte der Bodenmykobakterien. Zbl. Bakt. (2), 90, 428.

Krassilnikov, N. A. (1959). Diagnostik der Bakterien und Actinomyceten, pp. 39, 51, 203, 204. Jena: Gustav Fischer.

LIESke, R. (1921). Morphologie und Biologie der Strahlenpilze. Leipzig: Bornträger.

Lindegren, C. C. \& Mellon, R. R. (1933). Nuclear phenomena suggesting a sexual mechanism for the tubercle bacillus. Proc. Soc. exp. Biol., N.Y. 30, 110.

Luksch, F. (1930). Utber die Filtrierbarkeit der Tuberkelbazillen und andere Bakterien. Zbl. Bakt. (Abt. 1), 117, 1.

Mackie \& McCartney's Handbook of Bacteriology (1960), 10th edn., pp. 112, 192. Ed. by R. Cruickshank. Edinburgh and London: Livingstone.

MazeT, G. (1962). Contribution a l'étude morphologique du microbe de la tuberculose. Pr. Méd. 70, 697.

Mellon, R. R., Richardson, R. D. \& Fisher, L. W. (1933). Further studies on the life cycle of the avian tubercle bacillus. Proc. Soc. exp. Biol., N.Y. 30, 80.

MøLlgaARD, H. (1931). Über den fraglichen Entwicklungscyclus des Tuberkelbacillus. Beitr. Klin. Tuberk. 77, 83.

Moustardier, G., Dulong de Rosnay, C., Pasquier, P. \& Latrille, J. (1962). Formes anormales induites par la protamine chez quelques Bacillaceae. Annls. Inst. Pasteur, Paris, 102, 359.

Much, H. (1907). Über die granuläre, nach Ziehl nicht färbbare Form des Tuberkulosevirus. Beitr. Klin. Tuberk. 8, 85, 358.

Much, H. (1981). Die Variation des Tuberkelbacillus in Form und Wirkung. Beitr. Klin. Tuberk. 77, 60.

Nelus, L. (1955). The genus Mycococcus Krassilnikov. Bact. Rev. 19, 271. 
Novak, M. V. \& Henrici, A. T. (1933). Pleomorphic organism showing relationship between Staphylococci and Actinomycetes. J. infect. Dis. 52, 253.

Pra Y Armengol, R. (1931). Die verschiedenen Formen des Tuberkulose-Erregers. Beitr. Klin. Tuberk. 77, 47 .

Runyon, E. H. (1959). Anonymous mycobacteria in pulmonary disease. Med. Clin. N. Am. 43, 273.

Selkon, J. B. \& Mitchison, D. A. (1959). Atypical mycobacteria and drug-resistant tubercle bacilli isolated during a survey of untreated patients with pulmonary tuberculosis. Tubercle, Lond. 40, 141.

Sweany, H. C. (1926). Mutation forms of the tubercle bacillus. J. Am. med. Ass. 87, 1206.

Sweany, H. C. (1928). The granules of the tubercle bacillus. Am. Rev. Tuberc. 17, 53.

Tarshis, M. S., Weed, W. A., Kinselua, P. C., Parker, M. V. \& Dunham, W. B. (1955). Further experience with a new blood medium for the cultivation of Mycobacterium tuberculosis. Am. J. publ. Health, 45, 1157.

Topping, L. E. (1937). The predominant microorganisms in soils. Zbl. Bakt. (2), 97, 289.

VAUdREMER, A. (1923). Formes filtrantes des bacilles tuberculeux. Soc. Biol. 89, 80.

VAUDREmer, A. (1931). Études biologiques du bacilles tuberculeux. Les formes filtrantes, Beitr. Klin. Tuberk. 77, 16.

Waksman, S. A. (1959). The Actinomycetes, Vol. 1. pp. 53, 95, 102, 106. London: Baillière, Tindall and Cox.

Waksman, S. A. (1961). The Actinomycetes, Vol. 2, pp. 5, 21, 22. London: Baillière, Tindall and Cox.

Werssfeiler, J. \& Dwolaitskaja-Berischew, K. M. (1935). Die Wirkung des Wassers und physikochemischer Faktoren auf die Tuberkelbacillen. Beitr. Klin. Tuberk. 86, 151.

Xalabarder, C. (1954). El Origen del Bacilo de Koch, p. 68. Barcelona: Francisco Moragas.

Xalabarder, C. (1958). Electron microscopy of tubercle bacilli. Excerpta med. Sect xv, 11,467 .

\section{EXPLANATION OF PLATES}

Plate 1

Figs. 1-2. Morphology of a form 2 strain of M. tuberculosis (I 1418) on nutrient agar, after incubation for 2 days ('initial culture').

Fig. 1. Colonial morphology, $\times \mathbf{3} \cdot 4$.

Fig. 2. Cellular morphology, Gram stain, $\times 950$. Gram negative rods with or without endospores. Intracellular granules are not present.

Figs. 3-9. Various stages of the development of mycococci in the intermittently aerated digest broth cultures of the form 2 strain, Gram stain, $\times \mathbf{9 5 0}$ ('test cultures').

Fig. 3. 7 days. Uniformly stained Gram-variable rods, often long.

Fig. 4. 14 days. Some of the cells contain intracellular, Gram-positive granules.

Fig. 5. 21 days. Some of the granules are extracellular.

Fig. 6. 28 days. Some of the extracellular granules reach the size of $0.7 \mu$ diam.

Fig. 7. 35 days. Chains of granules within disintegrating rods.

Fig. 8. 35 days. Some free cocci are elongated.

Fig. 9. 42 days. Cocci have divided to form diplococci.

Figs. 10-11. Morphology of the mycococcus isolated from the 42 days old test culture, after incubation for 2 days on nutrient agar.

Fig. 10. Colonial morphology, $\times 3 \cdot 4$.

Fig. 11. Cellular morphology, Gram stain, $\times \mathbf{9 5 0}$. Gram-positive cocci with irregular shape and size. 


\section{Plate 2}

Figs. 1-10. Morphology of the mycococcus, isolated from the test cultures.

Figs. 1-2. Colonial morphology on peptone agar plates, $\times 3 \cdot 4$.

Fig. 1. 1 day. Size of colonies ranges between $0 \cdot 3-1 \cdot 3 \mathrm{~mm}$. diam.

Fig. 2. 14 days. Size of colonies ranges between $1.5-5.0 \mathrm{~mm}$. diam. Colonies differentiated by concentric rings into three sectors.

Figs. 3-6. Cellular morphology on peptone-agar plates. Figs. 3-5. Gram stain. Fig. 6. ZiehlNeelsen stain, $\times 2000$.

Fig. 3. 1 day. Size of cocci variable $(0 \cdot 4-1 \cdot 0 \mu$ diam.).

Fig. 4. 14 days. Some thick, elongated forms.

Fig. 5. 14 days. Some fine, thin elongated forms.

Fig. 6. 14 days. Division by binary fission in successive planes.

Figs. 7-10. Cellular morphology in peptone-broth. 14 days, Gram stain, $\times 2000$.

Fig. 7. Crescent-shaped form; one coccus has a short germination tube.

Fig. 8. Crescent-shaped form.

Fig. 9. Triangular form.

Fig. 10. Fine, short rods. Multiplication by lateral budding. 


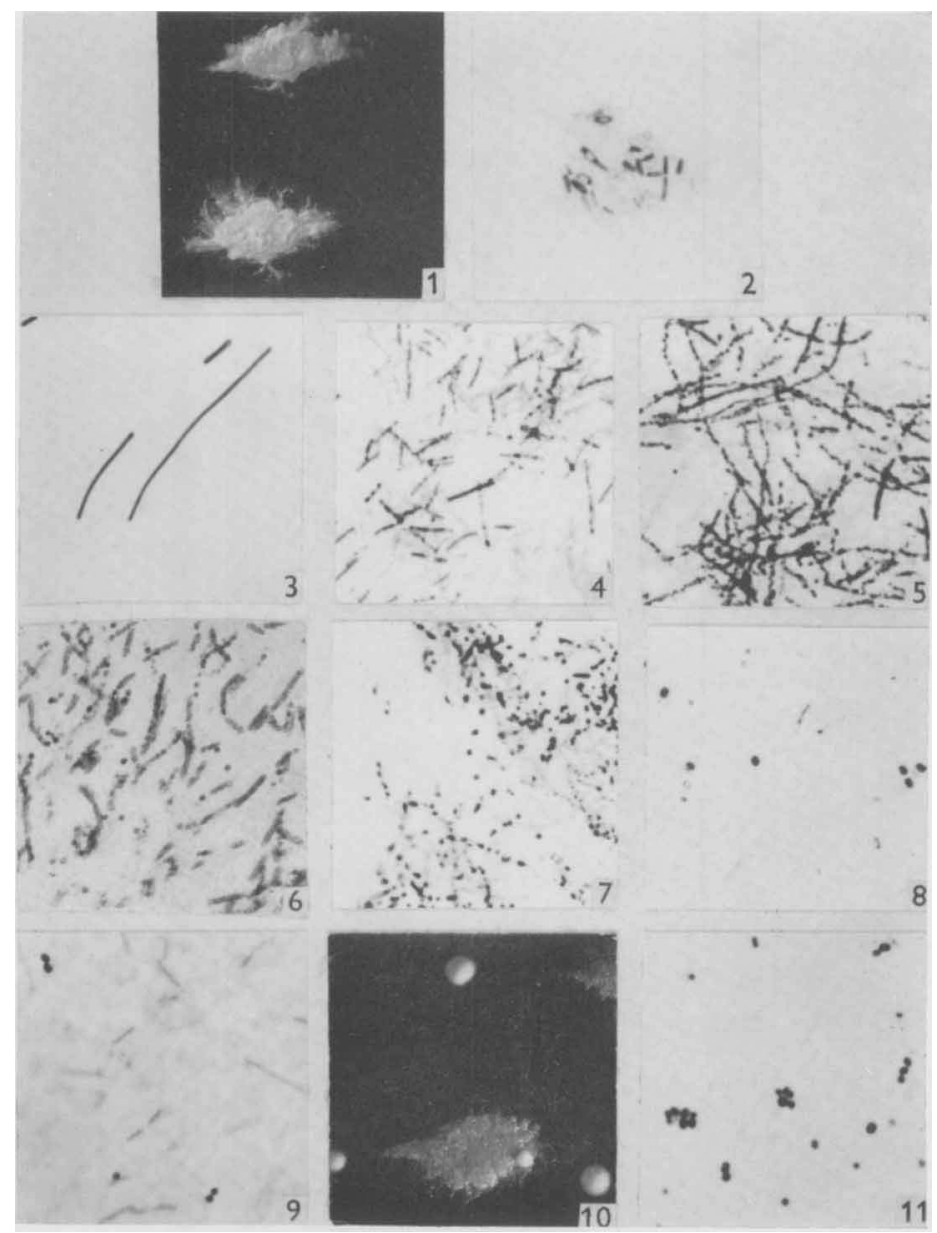

A. CSILLAG

(Facing p. 352) 
Journal of General Microbiology, Vol. 34, No. 2

Plate 2
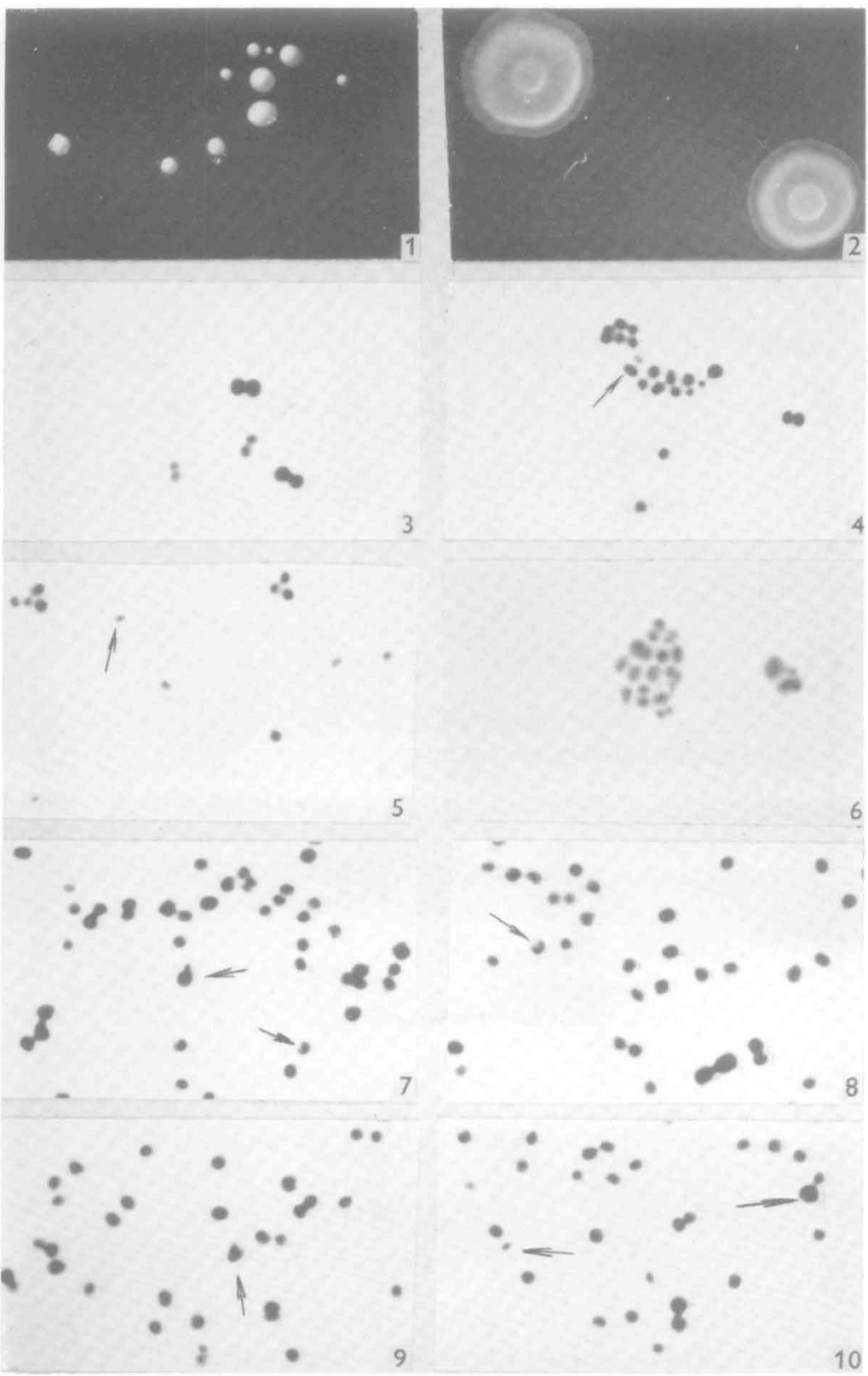

A. CSILLAG 